\title{
Mütrágyázás és meszezés hatása a 30 éves kompolti OMTK kísérletben
}

\author{
KÁDÁR IMRE és HOLLÓ SÁNDOR \\ MTA Talajtani és Agrokémiai Kutatóintézet, Budapest és \\ Károly Róbert Főiskola Fleischmann Rudolf Kutatóintézete, Kompolt
}

\section{Bevezetés és irodalmi áttekintés}

A különböző adagú és arányú NPK-mütrágyák hatásának vizsgálata céljából 1966-ban kezdődtek meg hazánkban az ún. egységes Országos Mütrágyázási Tartamkísérletek (OMTK). Az eredetileg 26 termőhelyen azonos metodikával indított nagyszabású kísérletsorozat tervét az akkori Földmüvelésügyi Minisztérium által megbízott kollektíva dolgozta ki Láng Géza vezetésével. A kísérleteket ún. „terített" vetésforgóban évente fokozatosan állították be. Minden kísérlet külön kódszámot kapott a beállítás évének és a forgónak megfelelően.

Az országos kísérletsorozat főbb eredményeit a DEBRECZENI \& DEBRECZENINÉ (1994) szerkesztésében megjelent monográfia, valamint a BLASKÓ és munkatársai (1998) által szerkesztett tanulmánykötet foglalta össze. A mélyfúrások, ill. a $\mathrm{NO}_{3}-\mathrm{N}$ mozgásával kapcsolatos eredményekről NÉMETH $(1995,1996)$ számolt be.

A továbbiakban az 1967 öszén indult B-17 jelü tartamkísérlet 30. évének eredményeit ismertetjük, melyek átfogó közlésére még nem kerülhetett sor. Ebben az évben a kukorica fejlődési rendellenességeket mutatott, ezért sokoldalú talaj- és növényvizsgálatokat kezdeményeztünk a talajtermékenységet gátló tényezők megismerése céljából. A tartamkísérlet néhány eredményéről korábbi közleményeink tudósítanak (HOLLÓ, 1994, 2003; Holló \& KÁDÁR, 2003).

\section{Anyag és módszer}

A kompolti kísérleti telep az É-Alföld hordalékkúpján, a Mátra és a Bükk hegységektől délre helyezkedik el. Talajtípusa a mezőségi és erdöségi talajok közötti átmenetet alkotó löszös üledékes, andezit málladékos agyagon kialakult mély humuszrétegü, nem karbonátos csernozjom barna erdőtalaj. E talajok különböző változatai az Alföld északi tájain mintegy 220 ezer ha területet foglalnak el. A talaj fizikai tulajdonságai kedvezőtlenek, nehezen művelhető. Szárazság hatására erősen zsugorodik, mélyen és szélesen repedezik, míg nedvesedve megduzzad. A talajvíz

Postai cím: KÁDÁR IMRE, MTA Talajtani és Agrokémiai Kutatóintézet, 1022 Budapest, Herman Ottó út 15.E-mail: kadar@rissac.hu 
8-10 m mélyen található, így a csapadék mennyisége és eloszlása a mütrágyák érvényesülése és a termésképzés szempontjából egyaránt meghatározó. Az agyagos vályog mechanikai összetételre utal a $40-48 \%$ agyag $(0,002 \mathrm{~mm}$ alatti frakció), illetve a mintegy $60 \%$-ot elérö leiszapolható rész $(0,01 \mathrm{~mm}$ alatti frakció). A humuszos réteg vastagsága $50-80 \mathrm{~cm}$, a szántott réteg humuszkészlete $2,5-3,0 \%$, nitrogénnel közepesen, foszforral gyengén, káliummal eredetileg jól ellátott.

A feltalaj erősen kilúgzott, meszet nem tartalmaz. Elsavanyodására utal az eredetileg is 5 alatti $\mathrm{pH}(\mathrm{KCl})$, illetve a $15-20$ közötti hidrolitos aciditás $\left(\mathrm{y}_{1}\right)$ érték. Az altalaj kötöttebb, kevésbé elsavanyodott, bázistelítettsége a $80 \%$-ot is meghaladhatja. Az uralkodó kationok mennyisége az S-érték \%-ában az alábbi: Ca $84, \mathrm{Mg} 10$, $\mathrm{Na} 4, \mathrm{~K}$ 2. Az S-érték itt 37, míg a T-érték 42 me/100 g-nak adódott. A feltalaj a bázisainak egy részét már elvesztette.

Az alsóbb talajrétegek kémhatása semleges körüli, $130-150 \mathrm{~cm}$ mélységben már lúgos. Ebben a rétegben a talaj mészfoltok és konkréciók formájában $\mathrm{CaCO}_{3}$-ot is tartalmaz. STEFANOVITS és DOMBÓVÁRINÉ (1985) agyagásványtani röntgendiffrakciós vizsgálatai szerint a $0-35 \mathrm{~cm}$-es rétegben kalcit és dolomit ásványok nem találhatók, míg ennél mélyebben mennyiségük 1\% körüli. A kísérleti területet reprezentáló talajszelvény főbb vizsgálati adatait az 1. táblázat szemlélteti a kísérlet beállítását követő években. Amint megfigyelhető, a mélységgel egyértelmúen emelkedik a $\mathrm{pH}(\mathrm{KCl})$, valamint az oldható $\mathrm{Mg}$ - és Na-készlete, ill. csökken az $\mathrm{y}_{1}$ hidrolitos aciditás és az oldható $\mathrm{NH}_{4}-\mathrm{N}, \mathrm{NO}_{3}-\mathrm{N}, \mathrm{K}, \mathrm{P}, \mathrm{Zn}$ és Cu koncentrációja. A $\mathrm{KCl}+\mathrm{EDTA}$-oldható Mn-mennyiséget viszont a genetikai szintek változása nem befolyásolja.

\section{1. táblázat}

A kísérleti hely talajszelvényének vizsgálati adatai a kísérlet beállítását követỏen (Csernozjom barna erdőtalaj, agyagos vályog, Kompolt)

\begin{tabular}{|c|c|c|c|c|}
\hline \multirow{2}{*}{ Vizsgált jellemzők* } & \multicolumn{4}{|c|}{ (2) Genetikai szint jele és mélysége cm-ben } \\
\hline & $\begin{array}{c}\text { A-szint } \\
0-32 \mathrm{~cm} \\
\end{array}$ & $\begin{array}{c}\text { B-szint } \\
32-76 \mathrm{~cm}\end{array}$ & $\begin{array}{c}\text { BC-szint } \\
76-112 \mathrm{~cm}\end{array}$ & $\begin{array}{l}\mathrm{C} \text {-szint } \\
112 \mathrm{~cm} \\
\end{array}$ \\
\hline $\begin{array}{l}\mathrm{pH}(\mathrm{KCl}) \\
\text { Hidrolitos aciditás }\left(\mathrm{y}_{1}\right)\end{array}$ & $\begin{array}{c}4,8 \\
18,9\end{array}$ & $\begin{array}{c}4,9 \\
14,7\end{array}$ & $\begin{array}{c}5,1 \\
10,6\end{array}$ & $\begin{array}{c}6,6 \\
-\end{array}$ \\
\hline $\mathrm{KCl}-\mathrm{Mg}(\mathrm{mg} \mathrm{Mg} / \mathrm{kg})$ & 643 & 1417 & 1429 & 1397 \\
\hline $\mathrm{AL}-\mathrm{K}\left(\mathrm{mg} \mathrm{K}_{2} \mathrm{O} / \mathrm{kg}\right)$ & 216 & 225 & 169 & 189 \\
\hline $\mathrm{KCl}+\mathrm{EDTA} \mathrm{Mn}(\mathrm{mg} \mathrm{Mn} / \mathrm{kg})$ & 70 & 73 & 68 & 72 \\
\hline $\mathrm{AL}-\mathrm{Na}(\mathrm{mg} \mathrm{Na} / \mathrm{kg})$ & 48 & 78 & 151 & 224 \\
\hline $\mathrm{AL}-\mathrm{P}\left(\mathrm{mg} \mathrm{P}_{2} \mathrm{O}_{5} / \mathrm{kg}\right)$ & 28 & 6 & 3 & 11 \\
\hline $\mathrm{KCl}+\mathrm{EDTA} \mathrm{Cu}(\mathrm{mg} \mathrm{Cu} / \mathrm{kg})$ & 6,6 & 5,5 & 4,4 & 3,5 \\
\hline $\mathrm{KCl}^{-\mathrm{NH}_{4}}(\mathrm{mg} \mathrm{N} / \mathrm{kg})$ & 6,4 & 4,3 & 3,4 & 3,1 \\
\hline $\mathrm{KCl}-\mathrm{NO}_{3}+\mathrm{NO}_{2}(\mathrm{mg} \mathrm{N} / \mathrm{kg})$ & 5,4 & 2,1 & 1,1 & 1,1 \\
\hline $\mathrm{KCl}+\mathrm{EDTA} \mathrm{Zn}(\mathrm{mg} \mathrm{Zn} / \mathrm{kg})$ & 3,5 & 1,2 & 1,6 & 2,6 \\
\hline Humusz \% & 2,6 & 1,5 & 0,9 & 0,8 \\
\hline
\end{tabular}

Vizsgálatok módszere: * MÉM NAK (1978) módszerfüzete szerint 
A B-17 jelü kísérletet 1967 őszén állították be 20 kezeléssel és 4 ismétlésben, azaz összesen 80 parcellában. A mütrágyaadagok a 4. és 21 . év után változtak, megemelkedtek a kor elvárásainak megfelelöen. Eltértek növényfajonként is. Amint a 2. táblázatban látható, a 4. év után a búza és a kukorica azonos NP-trágyázásban részesült. A kukorica nagyobb K-igényét a 21. évtöl a megemelt K-adagok tükrözik. A kísérlet dikultúrát jelent, búza-búza-kukorica-kukorica váltással. A P- és Kmütrágyákat, valamint a nitrogén felét ősszel szántás előtt, a nitrogén másik felét tavasszal szórjuk ki pétisó, szuperfoszfát és kálisó formájában.

\section{2. táblázat}

Mütrágyaadagok $\left(\mathrm{kg} \mathrm{N}, \mathrm{P}_{2} \mathrm{O}_{5}\right.$, ill. $\left.\mathrm{K}_{2} \mathrm{O} / \mathrm{ha} / \mathrm{év}\right)$ a B-17 jelü OMTK kísérletben (Csernozjom barna erdőtalaj, agyagos vályog, Kompolt)

\begin{tabular}{|c|c|c|c|c|c|c|}
\hline \multirow{2}{*}{$\begin{array}{c}\text { (1) } \\
\text { NPK- } \\
\text { szint }\end{array}$} & \multicolumn{3}{|c|}{ (2) } & \multicolumn{3}{|c|}{$\begin{array}{c}\text { (3) } \\
\text { Kukorica alá adott }\end{array}$} \\
\hline & 1-4. év & 5-20. év & 21. évtől & 1-4. év & 5-20. év & 21. évtől \\
\hline 0 & 0 & 0 & 0 & 0 & 0 & 0 \\
\hline $\mathrm{N}_{1}$ & 35 & 50 & 100 & 40 & 50 & 100 \\
\hline $\mathrm{N}_{2}$ & 70 & 100 & 150 & 80 & 100 & 150 \\
\hline $\mathrm{N}_{3}$ & 105 & 150 & 200 & 120 & 150 & 200 \\
\hline $\mathrm{N}_{4}$ & 140 & 200 & 250 & 160 & 200 & 250 \\
\hline $\mathrm{P}_{0}$ & 0 & 0 & 0 & 0 & 0 & 0 \\
\hline $\mathrm{P}_{1}$ & 35 & 50 & 60 & 35 & 50 & 60 \\
\hline $\mathrm{P}_{2}$ & 70 & 100 & 120 & 70 & 100 & 120 \\
\hline $\mathrm{P}_{3}$ & 105 & 150 & 180 & 105 & 150 & 180 \\
\hline $\mathrm{K}_{0}$ & 0 & 0 & 0 & 0 & 0 & 0 \\
\hline $\mathrm{K}_{1}$ & 70 & 100 & 100 & 100 & 100 & 200 \\
\hline
\end{tabular}

A 20. évet követően $8 \mathrm{t}$ /ha örölt mészkőporral a kísérlet I. és III. ismétléseit meszeztük, így az 4-tényezős 2 ismétlésessé vált. A kísérlet 30. évében Stira-SC hibridkukoricát vetettünk 1997. április 17-én. Július 8-án, 4-6 leveles korban parcellánként 20-20 föld feletti hajtás begyüjtésével átlagmintákat képeztünk. Ekkor a fiatal kukorica lilás-vörös elszíneződést, ill. mérgezési tüneteket mutatott a meszezetlen, föként a foszforral is gyengén ellátott parcellákon. Egyidejüleg talajmintavételre is sor került a szántott rétegből 20-20 pontminta átlagolásával parcellánként. A kísérletben végzett müveleteket és megfigyeléseket a 3. táblázat tekinti át.

A növénymintáknak mértük a friss és nedves tömegét, légszáraz anyag \%-át, majd a szárítást és a darálást követően azokat cc. $\mathrm{HNO}_{3}+\mathrm{cc} . \mathrm{H}_{2} \mathrm{O}_{2}$ elegyével elroncsoltuk és ICP-technikát alkalmazva meghatároztuk elemösszetételüket. Betakarításkor a légszáraz szemtermés tömegét regisztráltuk parcellánként. A talajmintákban az alábbi alapvizsgálatokat végeztük: $\mathrm{pH}\left(\mathrm{H}_{2} \mathrm{O}\right), \mathrm{pH}(\mathrm{KCl}), \mathrm{y}_{1}$-érték. Ezen túlmenően mértük a cc. $\mathrm{HNO}_{3}+c c . \mathrm{H}_{2} \mathrm{O}_{2}$ feltárással becsülhető „összes” elemkészletet, valamint az $\mathrm{NH}_{4}$-acetát+EDTA-oldható elemkoncentrációkat. Az ún. töménysavas „„̈sszes”, valamint a LAKANEN és ERVIÖ-féle (1971) elemfrakció analízisek 23 elemre terjedtek ki ICP méréstechnika alkalmazásával. 


\section{3. táblázat}

Az OMTK B-1730 sz. kukoricakísérletben végzett műveletek és megfigyelések 1996-1997 években (Csernozjom barna erdőtalaj, agyagos vályog, Kompolt)

\begin{tabular}{|c|c|c|}
\hline $\begin{array}{c}\text { (1) } \\
\text { Müveletek, megfigyelések }\end{array}$ & $\begin{array}{c}\text { (2) } \\
\text { Év, hó, nap }\end{array}$ & $\begin{array}{c}(3) \\
\text { Megjegyzés }\end{array}$ \\
\hline 1. Öszi búza elővetemény & 996. 07. 16. & Parc. kombájn (Claas Compact) \\
\hline 2. Tárcsázás & 1996. 07. 24. & Crystall + tárcsa + henger \\
\hline 3. Öszi NPK-mủtrágyázás & 1996. 10.01. & Parcellánként kézzel \\
\hline 4. Tárcsázás & 1996. 10. 01. & Crystall + nehéztárcsa \\
\hline 5. Öszi mé & 996. 11. 26. & Crystall + négyfejes vontatóeke \\
\hline 6. Kombiná & 1997.03. 26. & Crystall + kombinátor \\
\hline 7. Tav & 1997. 04. 02. & Parcellánként kézzel \\
\hline 8. Kombinátorozás & 1997. 04. 02. & Crystall + kombinátor \\
\hline 9. $\mathrm{Ve}$ & 1997. 04. 17. & SPC-6 vetőgép \\
\hline 10. V & 26. & permetezőgép (DMA 6) \\
\hline 11. Gyc & 5. 06. & MTZ + kultivátor \\
\hline 12. Gyomirtó & 1997. 06. 16. & MZZ + kultivátor \\
\hline 13. Növényr & 1997. 07. 08. & Parcellánként 20-20 db hajtás \\
\hline 14. Ta & 1997.07.09. & Parcellánként átlagminta \\
\hline $\begin{array}{l}\text { 15. Növénymintavétel aratáskor } \\
\text { (cső+szár) }\end{array}$ & 1997. 10. 01. & Parcellánként átlagminta \\
\hline 16. Betakar & & \\
\hline 17. Növénymintavétel kombájnoláskor & 1997. 10. 08. & Parcellánként a szemtermésből \\
\hline
\end{tabular}

Megjegyzés: Kukoricafajta: Hibrid Stira-SC, 70×30 cm-re vetve 5-7 cm mélyre, 16 kg/ha vetőmaggal

Ami a csapadékellátottságot illeti: az őszi búza elővetemény betakarítását követően az 1996. július és december közötti 6 hónap alatt 332 mm eső hullott. 1997. első három hónapjában (január-március) mindössze $35 \mathrm{~mm}$. Áprilisban 20, májusban 50, júniusban 80, júliusban 152, augusztusban 33, szeptemberben $37 \mathrm{~mm}$, azaz a kukorica aktív tenyészideje alatt $372 \mathrm{~mm}$ többé-kevésbé kedvező eloszlásban. Amennyiben a talaj az ezt megelőzően hullott $332+35=367$ mm csapadékot is befogadni és a kukorica számára tárolni volt képes, a kukorica elméletileg összesen $739 \mathrm{~mm}$ vízellátottsággal rendelkezhetett.

\section{Kísérleti eredmények}

Amint a 4. táblázatban látható, a 20. évben végzett meszezés utóhatása a kísérlet 30. évében (10 év után) még nyomon követhető. Az NP kontrollparcellákon 0,9 eltérés van mind a $\mathrm{pH}(\mathrm{KCl})$, mind a $\mathrm{pH}\left(\mathrm{H}_{2} \mathrm{O}\right)$ értékekben. A kísérlet fóátlagait tekintve 0,6 a különbség a pH-értékekben a meszezett parcellák javára. Megállapítható, hogy az elsavanyodás okozója alapvetőn a N-trágyázás, annak ellenére, hogy a 
4. táblázat

Kezelések hatása a szántott réteg kémhatására, hidrolitos aciditására $\left(\mathrm{y}_{1}\right)$ és a cc. $\mathrm{HNO}_{3}+\mathrm{cc}$. $\mathrm{H}_{2} \mathrm{O}_{2}$ oldható Sr- és P-készletére a meszezett és kontrollparcellákon, 1997-ben (Csernozjom barna erdőtalaj, B-17 OMTK kísérlet, Kompolt)

\begin{tabular}{|c|c|c|c|c|c|c|c|c|}
\hline \multirow{2}{*}{$\begin{array}{c}1) \\
\text { NP- } \\
\text { kezelés }\end{array}$} & \multicolumn{2}{|c|}{$\mathrm{pH}(\mathrm{KCl})$} & \multicolumn{2}{|c|}{$\mathrm{pH}\left(\mathrm{H}_{2} \mathrm{O}\right)$} & \multicolumn{2}{|c|}{$\mathrm{y}_{1}$} & $\mathrm{Sr}$ & $\mathrm{P}$ \\
\hline & $\begin{array}{c}(2) \\
\text { Meszezett } \\
\end{array}$ & $\begin{array}{c}(3) \\
\text { Kontroll } \\
\end{array}$ & $\begin{array}{c}(2) \\
\text { Meszezett }\end{array}$ & $\begin{array}{c}\text { (3) } \\
\text { Kontroll }\end{array}$ & $\begin{array}{c}(2) \\
\text { Meszezett }\end{array}$ & $\begin{array}{c}\text { (3) } \\
\text { Kontroll } \\
\end{array}$ & \multicolumn{2}{|c|}{$\mathrm{mg} / \mathrm{kg}^{*}$} \\
\hline $\mathrm{N}_{0} \mathrm{P}_{0}$ & 4,9 & 4,0 & 6,2 & 5,3 & 14 & 26 & 48 & 496 \\
\hline $\mathrm{N}_{1} \mathrm{P}_{0}$ & 4,5 & 4,0 & 5,6 & 5,0 & 22 & 28 & 50 & 522 \\
\hline $\mathrm{N}_{1} \mathrm{P}_{1}$ & 4,7 & 4,0 & 5,8 & 5,0 & 17 & 30 & 60 & 591 \\
\hline $\mathrm{N}_{1} \mathrm{P}_{2}$ & 4,5 & 3,8 & 5,6 & 4,9 & 20 & 29 & 71 & 690 \\
\hline $\mathrm{N}_{2} \mathrm{P}_{0}$ & 4,6 & 3,9 & 5,7 & 5,1 & 19 & 29 & 47 & 487 \\
\hline $\mathrm{N}_{2} \mathrm{P}_{1}$ & 4,4 & 4,0 & 5,5 & 5,1 & 20 & 28 & 59 & 578 \\
\hline $\mathrm{N}_{2} \mathrm{P}_{2}$ & 4,6 & 4,0 & 5,7 & 4,9 & 18 & 30 & 71 & 673 \\
\hline $\mathrm{N}_{3} \mathrm{P}_{0}$ & 4,2 & 3,9 & 5,3 & 5,0 & 23 & 28 & 48 & 515 \\
\hline $\mathrm{N}_{3} \mathrm{P}_{1}$ & 4,4 & 3,7 & 5,5 & 4,8 & 21 & 32 & 60 & 599 \\
\hline $\mathrm{N}_{3} \mathrm{P}_{2}$ & 4,5 & 3,8 & 5,5 & 4,8 & 22 & 32 & 70 & 694 \\
\hline $\mathrm{N}_{4} \mathrm{P}_{3}$ & 4,3 & 3,9 & 5,2 & 4,6 & 24 & 32 & 81 & 780 \\
\hline a) $\mathrm{SzD}_{5 \%}$ & 0,4 & 0,2 & 0,4 & 0,2 & 6 & 4 & 5 & 49 \\
\hline $\mathrm{N}_{1}$ & 4,6 & 3,9 & 5,7 & 5,0 & 19 & 29 & 61 & 601 \\
\hline $\mathrm{N}_{2}$ & 4,5 & 4,0 & 5,6 & 5,0 & 19 & 29 & 59 & 579 \\
\hline $\mathrm{N}_{3}$ & 4,4 & 3,8 & 5,4 & 4,8 & 22 & 31 & 59 & 603 \\
\hline $\mathrm{P}_{0}$ & 4,4 & 3,9 & 5,5 & 5,0 & 21 & 28 & 49 & 508 \\
\hline $\mathrm{P}_{1}$ & 4,5 & 3,9 & 5,6 & 5,0 & 19 & 30 & 60 & 589 \\
\hline $\mathrm{P}_{2}$ & 4,5 & 3,9 & 5,6 & 4,9 & 20 & 30 & 71 & 686 \\
\hline a) $\mathrm{SzD}_{5 \%}$ & 0,2 & 0,1 & 0,2 & 0,1 & 4 & 2 & 3 & 28 \\
\hline b) Főátlag & 4,5 & 3,9 & 5,6 & 5,0 & 20 & 29 & 60 & 599 \\
\hline a) $\mathrm{SzD}_{5 \%}$ & 0 , & & 0 , & & 2 & & & \\
\hline
\end{tabular}

Megjegyzés: Egyéb elemek átlagos mennyisége a kezelésektől függetlenül: Al 4,26\%, Fe $3,13 \%, \mathrm{~K} 0,63 \%$, Ca 0,48\%, Mg 0,48\%, összes-N 0,16\% (cc. $\mathrm{H}_{2} \mathrm{SO}_{4}$ feltárással); $\mathrm{Na} \mathrm{254,} \mathrm{Zn}$ 69, Cu 20 és B $9 \mathrm{mg} / \mathrm{kg}$. *A meszezett és a kontroll átlagában

N-trágya formáját pétisó, tehát a kevésbé savanyító Ca-ammónium-nitrát hatóanyag képviselte. A P- és K-mütrágyák savanyító hatását nem lehetett igazolni.

Az y $y_{1}$ mutatók alapján még a meszezett kontrolltalaj is savanyúnak minősül, míg a meszezetlen kísérlet az erősen savanyú kategóriába tartozik a hazai határértékek szerint. Az általánosan elfogadott mészigény számítási képlet szerint a $40-50 \mathrm{~K}_{\mathrm{A}}$ kötöttségnél $0,8 \mathrm{y}_{1}=\mathrm{CaCO}_{3}$ t/ha (MÉM NAK, 1979), tehát $15-20 \mathrm{t} /$ ha lehet a mészigény. Az erősen kötött talajok kiugróan nagy mészigénye közismerten a szerkezetjavítás céljait is szolgálhatja. Az $y_{1}$-értékek látványosan mutatják az elsavanyodás mértékét, valamint a korábbi meszezés utóhatását. A nem meszezett kísérlet átlaga 29, szemben a meszezett $y_{1}=20$ átlaggal. 
A cc. $\mathrm{HNO}_{3}+$ cc. $\mathrm{H}_{2} \mathrm{O}_{2}$ feltárással becsült „„összes” elemkészletben természetesen nehezebb kimutatni az esetleges változásokat a szántott rétegben, hiszen a hibahatárok nagyok. 30 év után azonban van esély bizonyos elemek dúsulását vagy esetleges fogyását regisztrálni. Elsősorban a mütrágyákkal nagyobb mennyiségben adott elemek jöhetnek tekintetbe, valamint egyes esetekben a növényi felvétel és a kilúgzással okozott veszteségek. A hazai szuperfoszfátgyártás alapanyagául szolgáló Kóla-foszfátok 2\% körüli mennyiségben tartalmazhatnak stronciumot (KÁDÁR, 1992).

A 4. táblázat eredményei szerint az abszolút kontroll-, ill. a P-kontroll talajok Sr-tartalma $48-50 \mathrm{mg} / \mathrm{kg}$, mely a P-trágyázással $70-80 \mathrm{mg} / \mathrm{kg}$ értékre nőtt, tehát a feltalaj Sr-készlete mintegy 50\%-kal emelkedett. Ugyanitt az „összes”-P készlet a P-kontroll parcellákon mért $500 \mathrm{mg} / \mathrm{kg}$ körüliröl $780 \mathrm{mg} / \mathrm{kg}$-ra ugrott a $\mathrm{P}_{3}$-kezelésben, mely $64 \%$-os gazdagodást jelent a talaj szántott rétegében. Meg kell említeni, hogy e módszerrel a talaj valódi összes elemkészlete teljes mértékben nem tárható fel, de a módszer utal a talaj összetételében végbement hatalmas változásokra. A meszezés az „összes” P- és Sr-készletet nem befolyásolta a talajban, adatainkat ezért a meszezett és nem meszezett parcellák átlagában közöljük.

A meszezett feltalajban $0,50 \%$, míg a kontrollban $0,45 \%$ kalciumot mértünk. A különbség 10 év után statisztikailag igazolható. Amennyiben ilyen módon becsülnénk a talajban maradt Ca-mennyiséget, a 3000 t/ha feltalaj 0,05\%-a 1,5 t Ca/ha, azaz $1,5 \times 2,5=3,75 \mathrm{t} \mathrm{CaCO}_{3} /$ ha mennyiségnek felelhetne meg. A $8 \mathrm{t} / \mathrm{ha}$ örölt mészkőpor közel fele tehát a szántott rétegben maradhatott. Hasonló becslést végezve a foszfor esetében feltételezhető, hogy a $\mathrm{P}_{3}$-kezelésekben adott kb. $4000 \mathrm{~kg} \mathrm{P}_{2} \mathrm{O}_{5} / \mathrm{ha} /$ 30 év trágyázásnál (amennyiben a növényi felvétel az adott $\mathrm{P}$ közel felét használta fel), a talajban maradt foszfor közelítően 50\%-a mutatható ki e módszerrel a szántott rétegben. A felhasznált 20-24 t szuperfoszfát/ha/30 év 1-2\%-os Sr-tartalmából kiindulva ugyanakkor a $\mathrm{P}_{3}$-kezelések talaja hektáronként mintegy $200-400 \mathrm{~kg}$ stronciummal gazdagodhatott a három évtized alatt. Mivel a feltalaj „összes” Srkészlete átlagosan itt $30 \mathrm{mg} / \mathrm{kg}$ értékkel nőtt (azaz 90-100 kg/ha mennyiséggel, a növényi felvétel pedig elhanyagolható), az adott $\mathrm{Sr} 25-50 \%$-a található a szántott rétegben. A Sr-kilúgozás mértéke nem ítélhető meg. Az $\mathrm{NH}_{4}$-acetát+EDTA-oldható Sr-készlet ugyanitt átlagosan $15 \mathrm{mg} / \mathrm{kg}$ értékkel emelkedett, tehát az „összes”-Sr fele volt „oldható” formában az 5. táblázat adatai szerint.

$\mathrm{Az}$,összes”-K-készlet $0,65 \%$ volt a káliummal trágyázott parcellákon, szemben a K-kontroll talaj 0,60\% K-tartalmával. A különbség a nagyszámú adat birtokában statisztikailag szintén igazolható. Egyéb vizsgált elemek átlagos „összes” mennyisége az alábbinak adódott a kezelésektől függetlenül: $\mathrm{Al} 4,26 \%, \mathrm{Fe} 3,1 \%, \mathrm{Mg}$ 0,48\%, összes-N (cc. $\mathrm{H}_{2} \mathrm{SO}_{4}$ feltárással) $0,16 \%, \mathrm{Mn} \mathrm{888,} \mathrm{Zn} \mathrm{69,} \mathrm{Cu} 20$ és B 9 $\mathrm{mg} / \mathrm{kg}$.

$\mathrm{Az} \mathrm{NH}_{4}$-acetát+EDTA-oldható frakcióban a változások pregnánsabban tükröződnek. A P-tartalom közel egy nagyságrenddel ugrik meg a trágyázatlan kontrollhoz képest a meszezett kísérlet $\mathrm{P}_{3}$-kezelésében. A szuperfoszfát 10-12\% S-tartalma nyomán ugyanitt 2-3-szorosára nő a szántott réteg S-készlete. Részben hasonló módon gazdagodik a feltalaj stronciumban. Ezzel szemben a Ba-koncentrációt a Ptrágyázás mérsékelte. A kísérlet főátlagai szerint a meszezés nem befolyásolta a 
foszfor és a stroncium átlagos mennyiségeit. A bárium némileg dúsult a meszezéssel, míg a kén mennyisége csökkent. A bárium a meszezőanyag alkotójaként kerülhet a talajba, akkumulálódhat. Úgy tűnik a $\mathrm{Ca}^{2+}$ kimosódásával a $\mathrm{SO}_{4}{ }^{2-}$, mint kíséröion, is veszteséget szenvedhet (5. táblázat).

\section{5. táblázat}

Kezelések hatása a szántott réteg $\mathrm{NH}_{4}$-acetát+EDTA-oldható elemkészletére a meszezett (M) és kontrollparcellákon (Ø), 1997-ben

(Csernozjom barna erdőtalaj, B-17 OMTK kísérlet, Kompolt)

\begin{tabular}{|c|c|c|c|c|c|c|c|c|}
\hline \multirow{2}{*}{$\begin{array}{c}\text { (1) } \\
\text { NP- } \\
\text { kezelés }\end{array}$} & \multicolumn{2}{|c|}{$\mathrm{P}_{2} \mathrm{O}_{5}, \mathrm{mg} / \mathrm{kg}$} & \multicolumn{2}{|c|}{$\mathrm{Ba}, \mathrm{mg} / \mathrm{kg}$} & \multicolumn{2}{|c|}{$\mathrm{S}, \mathrm{mg} / \mathrm{kg}$} & \multicolumn{2}{|c|}{$\mathrm{Sr}, \mathrm{mg} / \mathrm{kg}$} \\
\hline & $\mathrm{M}$ & $\varnothing$ & $\mathrm{M}$ & $\varnothing$ & $\mathrm{M}$ & $\varnothing$ & $\mathrm{M}$ & $\varnothing$ \\
\hline $\mathrm{N}_{0} \mathrm{P}_{0}$ & 14 & 29 & 40 & 40 & 12 & 18 & 12 & 17 \\
\hline $\mathrm{N}_{1} \mathrm{P}_{0}$ & 30 & 17 & 39 & 37 & 23 & 24 & 17 & 14 \\
\hline $\mathrm{N}_{1} \mathrm{P}_{1}$ & 39 & 45 & 36 & 32 & 32 & 38 & 20 & 20 \\
\hline $\mathrm{N}_{1} \mathrm{P}_{2}$ & 78 & 84 & 34 & 28 & 29 & 46 & 24 & 27 \\
\hline $\mathrm{N}_{2} \mathrm{P}_{0}$ & 19 & 17 & 38 & 39 & 18 & 23 & 14 & 14 \\
\hline $\mathrm{N}_{2} \mathrm{P}_{1}$ & 40 & 39 & 35 & 32 & 29 & 31 & 20 & 18 \\
\hline $\mathrm{N}_{2} \mathrm{P}_{2}$ & 76 & 76 & 35 & 28 & 31 & 38 & 26 & 24 \\
\hline $\mathrm{N}_{3} \mathrm{P}_{0}$ & 16 & 26 & 39 & 35 & 19 & 22 & 14 & 14 \\
\hline $\mathrm{N}_{3} \mathrm{P}_{1}$ & 36 & 51 & 36 & 29 & 26 & 38 & 18 & 21 \\
\hline $\mathrm{N}_{3} \mathrm{P}_{2}$ & 83 & 68 & 35 & 27 & 34 & 43 & 26 & 23 \\
\hline $\mathrm{N}_{4} \mathrm{P}_{3}$ & 134 & 103 & 29 & 21 & 46 & 58 & 30 & 27 \\
\hline a) $\mathrm{SzD}_{5 \%}$ & 21 & 17 & 3 & 6 & 10 & 10 & 4 & 5 \\
\hline $\mathrm{N}_{1}$ & 49 & 49 & 36 & 32 & 28 & 36 & 20 & 20 \\
\hline $\mathrm{N}_{2}$ & 45 & 44 & 36 & 33 & 26 & 31 & 20 & 19 \\
\hline $\mathrm{N}_{3}$ & 45 & 48 & 36 & 31 & 26 & 34 & 19 & 19 \\
\hline $\mathrm{P}_{0}$ & 22 & 20 & 39 & 37 & 20 & 23 & 15 & 14 \\
\hline $\mathrm{P}_{1}$ & 38 & 45 & 36 & 31 & 29 & 36 & 19 & 20 \\
\hline $\mathrm{P}_{2}$ & 79 & 76 & 35 & 28 & 32 & 42 & 25 & 25 \\
\hline a) $\mathrm{SzD}_{5 \%}$ & 12 & 10 & 2 & 3 & 6 & 6 & 2 & 3 \\
\hline b) Főátlag & 49 & 49 & 36 & 32 & 27 & 34 & 20 & 20 \\
\hline a) $\mathrm{SzD}_{5 \%}$ & \multicolumn{2}{|c|}{6} & \multicolumn{2}{|c|}{2} & \multicolumn{2}{|c|}{4} & \multicolumn{2}{|c|}{1} \\
\hline
\end{tabular}

Bizonyos esetekben az NP-hatások nem voltak igazolhatók, viszont a föhatásokban a meszezés vagy a K-trágyázás igen. A meszezett talaj több oldható $\mathrm{Ca}$, $\mathrm{Na}$ és $\mathrm{B}$ elemet tartalmazott részben a meszezőanyag összetételéből eredően. A meszezöanyagok B-készlete esetenként jelentős lehet, ritkán a növények számára mérgező mennyiséget is jelenthet. Esetünkben a meszezetlen talajon mért igen kis koncentráció azonban a mérés bizonytalanságát is tükrözi. Szegényebb viszont a meszezett talaj az oldható Al-, Fe-, M-, Ni-, Pb-, Co- és Cr-tartalmakat tekintve. Ezek a fémek közismerten inkább a savas közegben oldhatóbbak. Adatainkat a 6. táblázat szemlélteti. Meg kell említeni, hogy sajnos nem ismert az alkalmazott javítóanyag össze- 
tétele. Csak feltételezhető, hogy a meszezőanyaggal bevitt elemek okozhattak esetenként mennyiségi növekedést vagy hígulást a feltalajban. Az „összes”-Btartalomban pl. nem mutatható ki a meszezés vagy egyéb kezelés hatása, míg az „oldható” készlet szignifikánsan megnőtt. $\mathrm{Az} \mathrm{NH}_{4}$-acetát+EDTA-oldható elemtartalmakban fellépő változások a talajbani oldhatósági viszonyok módosulását tükrözhetik.

6. táblázat

Meszezés hatása a szántott réteg $\mathrm{NH}_{4}$-acetát+EDTA-oldható elemkészletére 1997-ben NPK-kezelések átlagai. Meszezés föhatások (Csernozjom barna erdőtalaj, B-17 OMTK kísérlet, Kompolt)

\begin{tabular}{|c|c|c|c|c|}
\hline \multirow{2}{*}{$\begin{array}{c}\text { Elem } \\
\text { jele }\end{array}$} & $\begin{array}{c}(2) \\
\text { Meszezett }\end{array}$ & $\begin{array}{c}(3) \\
\text { Ca-kontroll }\end{array}$ & $\begin{array}{c}(4) \\
\text { SzD }_{5 \%}\end{array}$ & Átlag \\
\cline { 2 - 5 } $\mathrm{Ca}$ & 3230 & 2590 & 130 & 2910 \\
$\mathrm{Fe}$ & 243 & 289 & 21 & 266 \\
$\mathrm{Al}$ & 138 & 215 & 16 & 177 \\
$\mathrm{Mn}$ & 88 & 117 & 7 & 102 \\
$\mathrm{Ba}$ & 36 & 32 & 2 & 34 \\
$\mathrm{Na}$ & 12,24 & 10,96 & 0,67 & 11,60 \\
$\mathrm{Ni}$ & 4,95 & 5,83 & 0,18 & 5,39 \\
$\mathrm{~Pb}$ & 3,52 & 4,00 & 0,36 & 3,76 \\
$\mathrm{Zn}$ & 1,37 & 0,98 & 0,25 & 1,18 \\
$\mathrm{Co}$ & 1,08 & 1,25 & 0,08 & 1,16 \\
$\mathrm{~B}$ & 0,11 & 0,02 & 0,03 & 0,06 \\
$\mathrm{Cr}$ & 0,10 & 0,16 & 0,06 & 0,13 \\
\hline
\end{tabular}

A K-trágyázás igazolhatóan csökkentette a $\mathrm{Ca}, \mathrm{Mg}, \mathrm{Mn}$, Ba és Co oldható mennyiségét a szántott rétegben, mely elemek a kálium antagonista kationjainak tekinthetők. A megfelelő kötési helyekről K által „kiszorított” antagonista elemek feltehetően nagyobb kimosódási veszteségeket szenvedtek az idők folyamán. A Kmütrágya fö összetevői a kálium és nátrium, mely elemek készlete nőtt a Ktrágyázással. A szántott réteg oldható K-készlete megduplázódott, a K-kontroll talajon mért $167 \mathrm{mg} / \mathrm{kg} 355 \mathrm{mg} / \mathrm{kg}$ értékre emelkedett. A Se-tartalom némileg szintén dúsult. Ennek oka ismeretlen (7. táblázat).

Összefoglalóan megállapítható, hogy a meszezés a talaj Ca-, Na-, Ba-, Zn- és Bkészletét növelte, mely elemekben a meszezöanyag gazdag lehet. A Mg-tartalom nem változott, magnéziumban gazdag meszezőanyagot (dolomitport) nem alkalmaztak. Csökkentette ugyanakkor azon elemek oldható koncentrációját, melyek inkább az elsavanyodó talajban mobilizálódhatnak: $\mathrm{Fe}, \mathrm{Al}, \mathrm{Mn}, \mathrm{Ni}, \mathrm{Pb}, \mathrm{Co}$ és $\mathrm{Cr}$. A S-készlet mérséklődése összefügghet a $\mathrm{Ca}^{2}+$ kíséröionjaként kilúgzódó $\mathrm{SO}_{4}$-S veszteséggel. Ugyanakkor a $\mathrm{Cu}$-, $\mathrm{Cd}$ - és Mo-mennyiség érdemben nem változott a kezelések eredményeképpen. A Cu átlagosan 3,48, Cd 0,09 és Mo 0,01 mg/kg tartalmat mutatott a kezelésektől függetlenül (7. táblázat). 


\section{7. táblázat}

K-trágyázás hatása a szántott réteg $\mathrm{NH}_{4}$-acetát+EDTA-oldható elemkészletére 1997-ben NPCa-kezelések átlagai. K-fóátlagok (Csernozjom barna erdőtalaj, B-17 OMTK kísérlet, Kompolt)

\begin{tabular}{|c|c|c|c|c|}
\hline \multirow{2}{*}{$\begin{array}{c}\text { Elem } \\
\text { jele }\end{array}$} & $\begin{array}{c}(2) \\
\text { K-trágyázás }\end{array}$ & $\begin{array}{c}(3) \\
\text { K-kontroll }\end{array}$ & $\begin{array}{c}(4) \\
\text { SzD }_{5 \%}\end{array}$ & Átlag \\
\cline { 2 - 5 } $\mathrm{Ca}$ & 2840 & 2980 & 130 & 2910 \\
$\mathrm{Mg}$ & 326 & 374 & 10 & 350 \\
$\mathrm{~K}_{2} \mathrm{O}$ & 355 & 167 & 16 & 265 \\
$\mathrm{Mn}$ & 99 & 105 & 7 & 102 \\
$\mathrm{Ba}$ & 32 & 36 & 2 & 34 \\
$\mathrm{Na}$ & 12,17 & 10,83 & 0,67 & 11,60 \\
$\mathrm{Se}$ & 1,49 & 1,16 & 0,24 & 1,32 \\
$\mathrm{Co}$ & 1,10 & 1,23 & 0,08 & 1,16 \\
\hline
\end{tabular}

Megjegyzés: Cu átlagosan 3,48, Cd 0,09, Mo 0,01 mg/kg koncentrációt mutatott a kezelésektöl függetlenül

A kukorica terméseredményeit a 8. táblázat részletezi. Amint az adatokból látható, a legkisebb hajtástömeget 4-6 leveles korban nem a 30 éve semmiféle trágyázásban nem részesült kontroll-, hanem a meszezetlen kísérlet egyoldalúan Ntrágyázott és elsavanyodott, P-hiányos parcellái adták. Itt az állomány antociános elszíneződést, mérgezési tüneteket mutatott. Meszezett talajon a fiatal kukorica kiegyenlítettebben fejlődött, az egyoldalú N-túlsúly negatív hatása kevésbé jelentkezett, a P-hiány kevésbé volt kifejezett.

Ismeretes, hogy a P-trágyázás tompíthatja az elsavanyodás káros következményeit. A növényre nem a savanyú közeg fejt ki negatív hatást önmagában, hanem a felszaporodó, toxikussá váló fémek (mint az Al, Fe, Mn stb.), melyeket a P foszfátok alakjában kicsaphat. És egyben a P-hiányt megszüntetve ellensúlyozza a Ntúlsúlyt, helyreállítja a kiegyensúlyozott N/P ellátást. Ez magyarázza a látványos $\mathrm{P}$ hatásokat a kísérletben 4-6 leveles korban. A hajtás légszáraz anyagtartalma átlagosan $13 \%$ körül ingadozott a fiatal korban (8. táblázat).

Betakarítás idejére a meszezés átlagos hatása csak mérsékelten jelentkezett, idővel a növény gyökerei a mélyebb és kevésbé elsavanyodott talajrétegekben fejlödhettek. Míg a 4-6 leveles kukorica hozamát a P-trágyázás és a meszezés befolyásolta döntően a feltalaj erősen savanyú viszonyai között, a későbbi fejlődés során a Nellátás vált meghatározóvá. Az $\mathrm{N}_{1}$-adag átlagosan $4 \mathrm{t} / \mathrm{ha}$, a meszezés csupán $2 \mathrm{t} / \mathrm{ha}$ szemterméstöbbletet eredményezett. A hosszú tenyészidő alatt a növények kielégíthették P- és K-igényeiket a trágyázatlan talajból is, betakarításkor a $\mathrm{P}$ és $\mathrm{K}$ hatásai már nem igazolhatók. Kedvezően csapadékos év hatásaként a talaj P- és K-formái jobban oldódnak, felvehetőségük javul, a trágyahatások visszaszorulnak. Az erősödő N-kimosódás és az intenzívebb biomassza-fejlődés nyomán viszont a N-trágya hatása kifejezettebbé válik (8. táblázat). 


\section{8. táblázat}

Kezelések hatása a kukorica hozamára 4-6 leveles korban és aratáskor a meszezett (M) és kontrollparcellákon (Ø) 1997-ben (Csernozjom barna erdőtalaj, B-17 OMTK kísérlet, Kompolt)

\begin{tabular}{|c|c|c|c|c|c|c|}
\hline \multirow{2}{*}{$\begin{array}{c}\text { (1) } \\
\text { NP- } \\
\text { kezelés }\end{array}$} & \multicolumn{2}{|c|}{$\begin{array}{c}\text { (2) } \\
\text { Friss hajtás, } \mathrm{g} / 20 \mathrm{db}\end{array}$} & \multicolumn{2}{|c|}{$\begin{array}{c}\text { (3) } \\
\text { Légszáraz hajtás, g/20 db }\end{array}$} & \multicolumn{2}{|c|}{$\begin{array}{c}(4) \\
\text { Szemtermés, } \mathrm{t} / \mathrm{ha}\end{array}$} \\
\hline & $\mathrm{M}$ & $\varnothing$ & $\mathrm{M}$ & $\varnothing$ & $\mathrm{M}$ & $\varnothing$ \\
\hline $\mathrm{N}_{0} \mathrm{P}_{0}$ & 655 & 447 & 80 & 64 & 8,8 & 7,6 \\
\hline $\mathrm{N}_{1} \mathrm{P}_{0}$ & 547 & 228 & 66 & 33 & 13,3 & 11,1 \\
\hline $\mathrm{N}_{1} \mathrm{P}_{1}$ & 800 & 448 & 91 & 59 & 13,1 & 11,5 \\
\hline $\mathrm{N}_{1} \mathrm{P}_{2}$ & 927 & 697 & 102 & 82 & 14,1 & 12,0 \\
\hline $\mathrm{N}_{2} \mathrm{P}_{0}$ & 571 & 240 & 67 & 34 & 14,2 & 11,0 \\
\hline $\mathrm{N}_{2} \mathrm{P}_{1}$ & 712 & 385 & 83 & 50 & 14,1 & 11,3 \\
\hline $\mathrm{N}_{2} \mathrm{P}_{2}$ & 966 & 651 & 110 & 77 & 14,4 & 12,4 \\
\hline $\mathrm{N}_{3} \mathrm{P}_{0}$ & 457 & 271 & 56 & 35 & 13,0 & 11,1 \\
\hline $\mathrm{N}_{3} \mathrm{P}_{1}$ & 579 & 409 & 70 & 60 & 13,6 & 12,0 \\
\hline $\mathrm{N}_{3} \mathrm{P}_{2}$ & 930 & 596 & 107 & 74 & 13,2 & 11,9 \\
\hline $\mathrm{N}_{4} \mathrm{P}_{3}$ & 1138 & 723 & 128 & 82 & 12,2 & 12,0 \\
\hline a) $\mathrm{SzD}_{5 \%}$ & 171 & 143 & 18 & 18 & 1,3 & 1,1 \\
\hline $\mathrm{N}_{1}$ & 758 & 471 & 86 & 58 & 13,5 & 11,5 \\
\hline $\mathrm{N}_{2}$ & 750 & 426 & 86 & 54 & 14,2 & 11,6 \\
\hline $\mathrm{N}_{3}$ & 655 & 425 & 78 & 56 & 13,3 & 11,7 \\
\hline $\mathrm{P}_{0}$ & 525 & 246 & 63 & 34 & 13,5 & 11,1 \\
\hline $\mathrm{P}_{1}$ & 697 & 428 & 81 & 56 & 13,6 & 11,6 \\
\hline $\mathrm{P}_{2}$ & 941 & 648 & 106 & 77 & 13,9 & 12,1 \\
\hline a) $\mathrm{SzD}_{5 \%}$ & 99 & 83 & 11 & 10 & 0,7 & 0,6 \\
\hline b) Főátlag & 739 & 455 & 85 & 58 & 13,3 & 11,4 \\
\hline a) $\mathrm{SzD}_{5 \%}$ & \multicolumn{2}{|c|}{86} & \multicolumn{2}{|c|}{9} & \multicolumn{2}{|c|}{0,4} \\
\hline
\end{tabular}

Most lássuk, hogyan alakul a fiatal hajtás elemösszetétele? Mint ismeretes, a növények tápláltsági állapotát összetételük tükrözi, így a talajok ellátottsága is közvetve becsülhetővé válik a levéldiagnosztikai adatok alapján. A 4-6 leveles korú fiatal kukorica hajtásának optimális összetétele a nemzetközi irodalmi adatok (BERGMANN \& NEUBERT, 1976) és saját vizsgálataink szerint (ELEK \& KÁDÁR, 1980; KÁDÁR, 1992) az alábbi: 3,5-5,0\% N, 3-4\% K, 0,3-0,7\% Ca, 0,3-0,5\% P, $0,3-0,6 \% \mathrm{Mg}, 0,3-0,5 \% \mathrm{~S}, 50-250 \mathrm{mg} / \mathrm{kg} \mathrm{Fe}, 30-300 \mathrm{mg} / \mathrm{kg} \mathrm{Mn}, 20-60 \mathrm{mg} / \mathrm{kg} \mathrm{Zn}$, $5-20 \mathrm{mg} / \mathrm{kg} \mathrm{Cu}, 6-25 \mathrm{mg} / \mathrm{kg} \mathrm{B}, 0,5-1,0 \mathrm{mg} / \mathrm{kg}$ Mo. A tápláltsági állapot megítéléséhez természetesen az elemek arányait is figyelembe kell venni. A kiegyensúlyozott föbb arányok, pl.: N/P 10-12, K/P 8-10, K/Ca 5-10, K/Mg 7-15, P/Fe 25-50, P/Mn 20-100, P/Zn 50-150. A 4-6 leveles kukorica tápláltsági állapotáról a 9. táblázat tájékoztat.

A 4-5\% N-tartalom kielégítő ellátottságot jelez. A humuszos talaj N-trágyázás nélkül is fedezte a növények igényét ebben a korban, a trágyázás vagy meszezés 
érdemi változást nem okozott a N-tartalomban. Az agyagos vályogtalaj bőséges Kellátást biztosított. K-trágyázás nélkül 4,30\%, K-trágyázással 4,83\% volt az átlagos $\mathrm{K}$-tartalom. Megemlítjük, hogy a $\mathrm{Ca} / \mathrm{K}$ antagonizmusra visszavezethetöen a nem meszezett talajon mért 4,67\% K-tartalom igazolhatóan 4,49\%-ra mérséklődött. Az említett határértékek alapján kielégítő ellátottságot jelzett a kén, magnézium és bór is a 9. táblázat lábjegyzetében közölt átlagos koncentrációi szerint. A magnézium a K-kontroll talajon kereken $0,29 \%$ készlettel rendelkezett, mely a K-trágyázotton $0,26 \%$-ra süllyedt igazolhatóan a $\mathrm{K} / \mathrm{Mg}$ ionantagonizmusra visszavezethetően.

A „normális” tartományban maradt a mangán koncentrációja. A 9. táblázat eredményei szerint a savanyúságot növelő N-szintek hatására emelkedik, míg a meszezéssel csökken a növényben az Mn-készlet. Az alumínium káros túlsúlyt mutat, mely a normális szintet nagyságrenddel haladja meg. Mindez hozzájárulhatott a

\section{9. táblázat}

Kezelések hatása a 4-6 leveles kukorica légszáraz hajtásának elemösszetételére a meszezett (M) és kontrollparcellákon (Ø) 1997. július 8-án (Csernozjom barna erdőtalaj, agyagos vályog, Kompolt)

\begin{tabular}{|c|c|c|c|c|c|c|c|c|}
\hline $\begin{array}{c}(1) \\
\text { NP- } \\
\text { kezelés }\end{array}$ & \multicolumn{2}{|c|}{$\mathrm{Mn}, \mathrm{mg} / \mathrm{kg}$} & \multicolumn{2}{|c|}{$\mathrm{Al} \%$} & \multicolumn{2}{c|}{$\mathrm{Ca} \%$} & \multicolumn{2}{|c|}{$\mathrm{P} \%$} \\
\cline { 2 - 9 } & $\mathrm{M}$ & $\varnothing$ & $\mathrm{M}$ & $\varnothing$ & $\mathrm{M}$ & $\varnothing$ & $\mathrm{M}$ & $\varnothing$ \\
\hline $\mathrm{N}_{0} \mathrm{P}_{0}$ & 127 & 166 & 0,28 & 0,20 & 0,49 & 0,53 & 0,42 & 0,40 \\
$\mathrm{~N}_{1} \mathrm{P}_{0}$ & 171 & 213 & 0,27 & 0,28 & 0,54 & 0,60 & 0,41 & 0,34 \\
$\mathrm{~N}_{1} \mathrm{P}_{1}$ & 139 & 160 & 0,20 & 0,20 & 0,57 & 0,58 & 0,46 & 0,40 \\
$\mathrm{~N}_{1} \mathrm{P}_{2}$ & 149 & 236 & 0,17 & 0,20 & 0,60 & 0,65 & 0,50 & 0,41 \\
$\mathrm{~N}_{2} \mathrm{P}_{0}$ & 152 & 205 & 0,21 & 0,25 & 0,57 & 0,66 & 0,43 & 0,32 \\
$\mathrm{~N}_{2} \mathrm{P}_{1}$ & 148 & 228 & 0,18 & 0,24 & 0,58 & 0,70 & 0,45 & 0,34 \\
$\mathrm{~N}_{2} \mathrm{P}_{2}$ & 144 & 199 & 0,13 & 0,21 & 0,63 & 0,65 & 0,52 & 0,39 \\
$\mathrm{~N}_{3} \mathrm{P}_{0}$ & 148 & 245 & 0,20 & 0,31 & 0,58 & 0,62 & 0,39 & 0,33 \\
$\mathrm{~N}_{3} \mathrm{P}_{1}$ & 174 & 250 & 0,26 & 0,23 & 0,57 & 0,67 & 0,40 & 0,35 \\
$\mathrm{~N}_{3} \mathrm{P}_{2}$ & 191 & 222 & 0,16 & 0,23 & 0,67 & 0,63 & 0,50 & 0,38 \\
$\mathrm{~N}_{4} \mathrm{P}_{3}$ & 172 & 228 & 0,14 & 0,20 & 0,68 & 0,60 & 0,60 & 0,47 \\
a) $\mathrm{SzD}_{5 \%}$ & 61 & 65 & 0,11 & 0,11 & 0,10 & 0,07 & 0,08 & 0,04 \\
$\mathrm{~N}_{1}$ & 153 & 203 & 0,21 & 0,22 & 0,57 & 0,61 & 0,46 & 0,39 \\
$\mathrm{~N}_{2}$ & 148 & 210 & 0,18 & 0,23 & 0,59 & 0,67 & 0,47 & 0,35 \\
$\mathrm{~N}_{3}$ & 171 & 239 & 0,21 & 0,26 & 0,61 & 0,64 & 0,43 & 0,35 \\
$\mathrm{P}_{0}$ & 157 & 221 & 0,23 & 0,28 & 0,56 & 0,63 & 0,41 & 0,33 \\
$\mathrm{P}_{1}$ & 153 & 213 & 0,21 & 0,22 & 0,57 & 0,65 & 0,43 & 0,37 \\
$\mathrm{P}_{2}$ & 161 & 219 & 0,15 & 0,21 & 0,64 & 0,64 & 0,51 & 0,40 \\
a) $\mathrm{SzD}_{5 \%}$ & 35 & 37 & 0,06 & 0,07 & 0,06 & 0,04 & 0,05 & 0,03 \\
b) Fóátlag & 156 & 215 & 0,20 & 0,23 & 0,59 & 0,63 & 0,46 & 0,37 \\
a) $\mathrm{SzD}_{5 \%}$ & \multicolumn{2}{|c|}{21} & \multicolumn{2}{|c|}{0,04} & & 0,05 & & 0,03 \\
\hline
\end{tabular}

Megjegyzés: A N 4-5\%, K 4-5\%, S 0,32\%, Mg 0,27\% és Fe 0,21\% átlagosan. A Na 28, B 8, $\mathrm{Ni} 1,2, \mathrm{Cr} 1,0, \mathrm{Cd} 0,3$ és Co $0,3 \mathrm{mg} / \mathrm{kg}$ átlagosan a kezelésektöl függetlenül 
fiatal kukorica fejlődési rendellenességéhez. Az Al-túlsúlyt a P-trágyázás és enyhébb mértékben a meszezés mérsékelte.

Összességében a kalcium szintén a „normális” tartományban maradt. A talajsavanyodás depresszív hatása élettanilag nem vezethető vissza a Ca-hiányra. Az együttes NP-adagok nyomán enyhén nőtt a $\mathrm{Ca}$ beépülése a növényi szövetekbe. A meszezés utóhatása vagy a K-trágyázás érdemben nem módosította a Ca-koncentrációt. A meszezetlen kísérletben a P-kontroll talajon termett kukorica kicsi, 0,33\% körüli P-tartalmat jelez. A P-trágyázás és a meszezés egyaránt javította a foszfor beépülését, mely így a jó ellátottsági tartományba emelkedett (9. táblázat).

A Zn-tartalom megfelelö ellátottságra utal. A $\mathrm{P} / \mathrm{Zn}$ és $\mathrm{Ca} / \mathrm{Zn}$ antagonizmus miatt koncentrációja enyhén süllyed. A Sr-beépülést döntően a P-kínálat módosítja. A szuperfoszfátok Sr-készlete, esetleg a $\mathrm{P} / \mathrm{Sr}$ szinergizmusa is tükröződhet abban, hogy a hajtás Sr-tartalma 2-3-szorosára nöhet a legnagyobb NP-szinten. A meszezés némileg mérsékli a koncentrációját a $\mathrm{Ca} / \mathrm{Sr}$ antagonizmus nyomán. A bárium

10. táblázat

Kezelések hatása a 4-6 leveles kukorica légszáraz hajtásának Zn-, Sr-, Ba- és Cu-tartalmára a meszezett (M) és kontrollparcellákon (Ø) 1997. július 8-án

(Csernozjom barna erdőtalaj, B-17 OMTK kísérlet, Kompolt)

\begin{tabular}{|c|c|c|c|c|c|c|c|c|}
\hline $\begin{array}{c}(1) \\
\mathrm{NP}\end{array}$ & \multicolumn{2}{|c|}{$\mathrm{Zn}, \mathrm{mg} / \mathrm{kg}$} & \multicolumn{2}{|c|}{$\mathrm{Sr}, \mathrm{mg} / \mathrm{kg}$} & \multicolumn{2}{c|}{$\mathrm{Ba}, \mathrm{mg} / \mathrm{kg}$} & \multicolumn{2}{c|}{$\mathrm{Cu}, \mathrm{mg} / \mathrm{kg}$} \\
kezelés & $\mathrm{M}$ & $\varnothing$ & $\mathrm{M}$ & $\varnothing$ & $\mathrm{M}$ & $\varnothing$ & $\mathrm{M}$ & $\varnothing$ \\
\hline $\mathrm{N}_{0} \mathrm{P}_{0}$ & 55 & 52 & 22 & 34 & 19 & 20 & 15 & 13 \\
$\mathrm{~N}_{1} \mathrm{P}_{0}$ & 56 & 51 & 32 & 40 & 22 & 29 & 13 & 13 \\
$\mathrm{~N}_{1} \mathrm{P}_{1}$ & 58 & 52 & 38 & 47 & 17 & 19 & 12 & 11 \\
$\mathrm{~N}_{1} \mathrm{P}_{2}$ & 52 & 50 & 51 & 63 & 16 & 20 & 10 & 10 \\
$\mathrm{~N}_{2} \mathrm{P}_{0}$ & 63 & 54 & 32 & 42 & 20 & 27 & 13 & 12 \\
$\mathrm{~N}_{2} \mathrm{P}_{1}$ & 57 & 52 & 38 & 53 & 18 & 23 & 12 & 10 \\
$\mathrm{~N}_{2} \mathrm{P}_{2}$ & 52 & 53 & 52 & 61 & 14 & 19 & 10 & 9 \\
$\mathrm{~N}_{3} \mathrm{P}_{0}$ & 58 & 52 & 29 & 51 & 19 & 29 & 13 & 11 \\
$\mathrm{~N}_{3} \mathrm{P}_{1}$ & 55 & 51 & 36 & 58 & 21 & 22 & 11 & 10 \\
$\mathrm{~N}_{3} \mathrm{P}_{2}$ & 50 & 47 & 52 & 58 & 16 & 20 & 10 & 9 \\
$\mathrm{~N}_{4} \mathrm{P}_{3}$ & 49 & 48 & 67 & 66 & 14 & 27 & 9 & 8 \\
a) $\mathrm{SzD}_{5 \%}$ & 6 & 5 & 8 & 8 & 7 & 7 & 2 & 2 \\
$\mathrm{~N}_{1}$ & 55 & 51 & 40 & 50 & 18 & 23 & 12 & 11 \\
$\mathrm{~N}_{2}$ & 57 & 53 & 41 & 52 & 17 & 23 & 12 & 11 \\
$\mathrm{~N}_{3}$ & 54 & 50 & 39 & 56 & 18 & 24 & 12 & 10 \\
$\mathrm{P}_{0}$ & 59 & 52 & 31 & 44 & 20 & 28 & 13 & 12 \\
$\mathrm{P}_{1}$ & 57 & 52 & 38 & 53 & 18 & 22 & 12 & 11 \\
$\mathrm{P}_{2}$ & 51 & 50 & 52 & 61 & 15 & 20 & 10 & 9 \\
a) $\mathrm{SzD}_{5}$ & 4 & 3 & 5 & 5 & 4 & 4 & 1 & 1 \\
b) Fóátlag & 55 & 51 & 40 & 52 & 18 & 23 & 12 & 10 \\
a) $\mathrm{SzD}_{5 \%}$ & & 3 & & 3 & & 3 & & 1 \\
\hline
\end{tabular}


beépülését a meszezés és a P-trágyázás egyaránt gátolta. A réz szintén a kielégítő tartományban ingadozott. Az együttes NP-trágyázással, főként a P-adagok növelésével beépülése mérséklődött. A meszezett kísérletben a $\mathrm{Cu}$ mintegy 20\%-kal nagyobb akkumulációt mutatott (10. táblázat).

\section{Összefoglalás}

Az Országos Egységes Mütrágyázási Tartamkísérletekhez (OMTK) tartozó B1730 sz. kisparcellás kísérlet Kompolton beállított változatát vizsgáltuk 1997-ben, a kísérlet 30. évében. A csernozjom barna erdőtalaj szántott rétege meszet nem tartalmaz, erösen kilúgzott, a $\mathrm{pH}(\mathrm{KCl})$ eredetileg 5 körüli, a hidrolitos aciditás $15-25$ közötti, agyagtartalma 40-48 \%, humusztartalma 2,5-3,0\%, nitrogénnel közepesen, foszforral gyengén, míg káliummal kielégítően ellátott. A talajvíz 8-10 m mélyen helyezkedik el, a termőhely aszályérzékeny. A föbb eredmények:

- A kísérlet 30. évében a $8 \mathrm{t}$ /ha örölt mészkőporral végzett meszezés utóhatása nyomon követhető, meszezett talajon a $\mathrm{pH}(\mathrm{KCl})$ és a $\mathrm{pH}\left(\mathrm{H}_{2} \mathrm{O}\right)$ egyaránt 0,6 egységgel nagyobb, az y $y_{1}$ pedig 29-röl 20-ra csökkent.

- A talajok cc. $\mathrm{HNO}_{3}+$ cc. $\mathrm{H}_{2} \mathrm{O}_{2}$ feltárással becsült „összes”-P készlete 500 $\mathrm{mg} / \mathrm{kg}$ mennyiségről $780 \mathrm{mg} / \mathrm{kg}$-ra nőtt a maximális P-adaggal, mely 64\%-os gazdagodást jelent a szántott rétegben. Ezzel együtt az „összes”-Sr készlet mintegy $50 \%$-kal emelkedett a szuperfoszfátok 2\% Sr-szennyezéséből eredően. A kontrolltalajban átlagosan $0,45 \%$, a meszezetten $0,50 \%$ Ca-tartalmat mértünk. A különbség statisztikailag igazolható volt. K-trágyázással a K-készlet 0,60\%-ról 0,65\%-ra emelkedett. E módszerrel az Al 4,26\%, Fe 3,1\%, Mg 0,48\%; Mn 888, Zn 69, Cu 20 és B $9 \mathrm{mg} / \mathrm{kg}$ mennyiségnek adódott.

- Az NH $\mathrm{NH}_{4}$-acetát+EDTA-oldható (LAKANEN \& ERVIÖ, 1971) frakcióban foszfor hatására nagyságrenddel nőhet a $\mathrm{P}, 2-3$-szorosára a $\mathrm{S}$ és Sr mennyisége a feltalajban. A meszezett talaj gazdagabb volt $\mathrm{Ca}, \mathrm{Na}, \mathrm{B}, \mathrm{Ba}$ és $\mathrm{Zn}$ elemekben a meszezőanyag összetételére visszavezethetően. Szegényebb volt viszont az Al, Fe, $\mathrm{Mn}, \mathrm{Ni}, \mathrm{Pb}$, Co és $\mathrm{Cr}$ elemeket tekintve, mely fémek inkább a savas közegben oldhatóbbak.

- A K-kontroll talajon mért $\mathrm{K}_{2} \mathrm{O}$-mennyiség 167-ről 355 mg/kg értékre emelkedett K-trágyázással. Némileg nőtt a Na-készlet is, mely a K-trágya összetevője. A $\mathrm{Ca}, \mathrm{Mg}, \mathrm{Mn}, \mathrm{Ba}$ és Co oldható mennyisége viszont csökkent. Feltehetően ezek az antagonista fémek nagyobb kimosódási veszteségeket szenvedtek, kiszorulva a megkötési helyeikröl.

- A legkisebb hajtástömeget 4-6 leveles korban nem az abszolút kontroll-, hanem az egyoldalú N-trágyázásban részesült, erősen elsavanyodott P-hiányos kezelések adták. Az állomány itt mérgezési tüneteket mutatott. Meszezett talajon a Phiány kevésbé jelentkezett. Érés idejére a P-hatások elmaradtak és a meszezés befolyása is mérséklődött, a növény gyökerei a mélyebb és kevésbé savanyú közegben fejlődhettek. Meghatározóvá a N-adag vált, 4 t/ha terméstöbbletet eredményezve, míg a meszezés utóhatásaként 2 t/ha terméstöbbletet regisztráltunk. A K-trágyázás hatástalan maradt ezen a káliummal jól ellátott termőhelyen. 
- A 4-6 leveles kukorica hajtása levéldiagnosztikai szempontból kielégítő ellátottságot jelzett a N-, K-, Ca-, Mg-, Mn-, Zn-, Cu- és B-koncentrációt tekintve. A Ptrágyázás és a meszezés egyaránt javította a foszfor beépülését a növénybe, így az eredetileg gyenge ellátottság a kielégítő tartományba került. Nyomon követhető volt a $\mathrm{P} / \mathrm{Al}, \mathrm{P} / \mathrm{Zn}, \mathrm{P} / \mathrm{Cu}, \mathrm{Ca} / \mathrm{K}, \mathrm{Ca} / \mathrm{Sr}, \mathrm{Ca} / \mathrm{Zn}$ és $\mathrm{K} / \mathrm{Mg}$ antagonizmus, illetve a $\mathrm{P} / \mathrm{Sr}$ szinergizmus a hajtás összetételében.

- A hajtások Al- és Fe-koncentrációja nagyságrenddel haladta meg a „normális” összetételt. Mindez hozzájárulhatott a fiatal kukorica rendellenes fejlődéséhez, a toxicitási tünetek kifejlődéséhez.

Kulcsszavak: mütrágyázás, meszezés, tartamhatás, kukorica, elemforgalom

\section{Irodalom}

Bergmann, W. \& Neubert, P., 1976. Pflanzendiagnose und Pflanzenanalyse. VEB Gustav Fischer Verlag. Jena.

BLASKÓ L. et al., (szerk.) 1998. Mütrágyázás, talajsavanyodás és meszezés összefüggései az OMTK kísérlethálózat talajain. OMTK kiadvány. Kompolt-Karcag.

BuZÁs I. et al. (szerk.), 1979. Mütrágyázási irányelvek és üzemi számítási módszer. MÉM NAK. Budapest.

DeBRECZENI B. \& DeBRECZENI B.-NÉ, 1994. Trágyázási kutatások 1960-1990. Akadémiai Kiadó. Budapest.

ELEK É. \& KÁDÁR, 1980. Állókultúrák és szabadföldi növények mintavételi módszere. MÉM Növényvédelmi és Agrokémiai Központ. Budapest.

Holló S., 1994. A Kompolton végzett tartamkísérletek. In: Trágyázási kutatások 19601990. (Szerk.: DEBRECZENI B. \& DeBRECZENI B.-NÉ) 46-50. Akad. Kiadó. Bpest.

HoLLÓ S., 2003. A mütrágyázás és a mészállapot összefüggései csernozjom barna erdötalajon. In: Mütrágyázás, talajsavanyodás és meszezés összefüggései az OMTK kísérlethálózat talajain. (Szerk.: BLASKó L. \& ZSIGRAI GY.) 181-216. OMTK kiadványa. Karcag-Keszthely.

Holló S. \& KÁDÁR I., 2003. A mütrágyázás és a meszezés hatása a talaj termékenységére. In: Mütrágyázás, talajsavanyodás és meszezés összefüggései az OMTK kísérlethálózat talajain. (Szerk.: BLASKÓ L. \& ZsIGRAI GY.) 217-224. OMTK kiadványa. Karcag-Keszthely.

KÁDÁR I., 1992. A növénytáplálás alapelvei és módszerei. MTA TAKI. Budapest.

LAKANEN, E. \& ERVIÖ, R., 1971. A comparison of eight extractants for the determination of plant available micronutrients in soils. Acta Agr. Fenn. 123. 223-232.

MÉM NAK, 1978. A TVG tápanyagvizsgáló laboratórium módszerfüzete. Budapest.

NÉMETH, T., 1995. Nitrogen in Hungarian soils - nitrogen management relation to groundwater protection. J. Contam. Hydrology. 20. 185-208.

NÉMETH T., 1996. Talajaink szervesanyag-tartalma és nitrogénforgalma. MTA TAKI. Budapest.

STEFANOVITS P. \& DOMBÓVÁRI L.-NÉ, 1985. A talajok agyagásvány-társulásainak térképe. Agrokémia és Talajtan. 34. 317-330.

Érkezett: 2005. november 11. 


\title{
Studies on the Effect of Mineral Fertilization and Liming in the First 30 Years of the National Long-Term Mineral Fertilization Trials in Kompolt
}

\author{
I. KÁDÁR and S. HOLLÓ
}

Research Institute for Soil Science and Agricultural Chemistry (RISSAC) of the Hungarian Academy of Sciences, Budapest and Rudolf Fleischmann Research Institute of Károly Róbert College, Kompolt (Hungary)

\section{Summary}

The small-plot experiment (No. B-1730) set up in Kompolt as part of the National Long-Term Mineral Fertilization Trials was evaluated in 1997 , in the $30^{\text {th }}$ year. The ploughed layer of the chernozem brown forest soil contained no lime and was intensively leached. The $\mathrm{pH}(\mathrm{KCl})$ was originally around 5 , the hydrolytic acidity $15-25$, the clay content $40-48 \%$ and the humus content $2.5-3.0 \%$. The nutrient supplies were moderate for $\mathrm{N}$, poor for $\mathrm{P}$ and satisfactory for $\mathrm{K}$. The groundwater was at a depth of 8-10 $\mathrm{m}$ and the area was prone to drought. The main results were as follows:

- In the $30^{\text {th }}$ year of the experiment the after-effects of liming with $8 \mathrm{t} /$ ha ground limestone could still be observed; on limed soil the $\mathrm{pH}(\mathrm{KCl})$ and the $\mathrm{pH}\left(\mathrm{H}_{2} \mathrm{O}\right)$ values were both 0.6 units higher, while $\mathrm{y}_{1}$ had dropped from 29 to 20 .

- The "total" $\mathrm{P}$ content of the soils, estimated by digestion with cc. $\mathrm{HNO}_{3}+\mathrm{cc}$. $\mathrm{H}_{2} \mathrm{O}_{2}$, increased from 500 to $780 \mathrm{mg} / \mathrm{kg}$ for the maximum $\mathrm{P}$ rate, representing an increase of $64 \%$ in the ploughed layer. At the same time the "total" Sr content rose by approx. $50 \%$, due to the $2 \% \mathrm{Sr}$ contamination of superphosphate. The Ca content averaged $0.45 \%$ in the control soil and $0.50 \%$ in limed treatments. The difference was statistically significant. As the result of $\mathrm{K}$ fertilization the $\mathrm{K}$ reserves increased from $0.60 \%$ to $0.65 \%$. Using the same method, the contents of other elements were: $\mathrm{Al} 4.26 \%, \mathrm{Fe}$ 3.1\%, Mg 0.48\%, Mn $888 \mathrm{mg} / \mathrm{kg}, \mathrm{Zn} 69 \mathrm{mg} / \mathrm{kg}, \mathrm{Cu} 20 \mathrm{mg} / \mathrm{kg}$ and B $9 \mathrm{mg} / \mathrm{kg}$.

- In response to $\mathrm{P}$ fertilization the quantity of $\mathrm{P}$ in the $\mathrm{NH}_{4}$-acetate + EDTA-soluble fraction (LAKANEN \& ERVIÖ, 1971) increased by an order of magnitude in the topsoil, while that of $\mathrm{S}$ and $\mathrm{Sr}$ was doubled or tripled. Limed soil was richer in $\mathrm{Ca}, \mathrm{Na}, \mathrm{B}, \mathrm{Ba}$ and $\mathrm{Zn}$, due to the composition of the liming agent, but it was poorer in $\mathrm{Al}, \mathrm{Fe}, \mathrm{Mn}, \mathrm{Ni}$, $\mathrm{Pb}, \mathrm{Co}$ and $\mathrm{Cr}$, as these elements are more readily soluble in an acidic medium.

- In the $\mathrm{K}$ control soil the quantity of $\mathrm{K}_{2} \mathrm{O}$ increased from 167 to $355 \mathrm{mg} / \mathrm{kg}$ after $\mathrm{K}$ fertilization. There was also a slight increase in the $\mathrm{Na}$ reserves, due to the composition of the $\mathrm{K}$ fertilizer, while the soluble quantities of $\mathrm{Ca}, \mathrm{Mg}, \mathrm{Mn}, \mathrm{Ba}$ and $\mathrm{Co}$ decreased. It can be assumed that these antagonistic metals suffered greater leaching losses after being replaced at their binding sites.

- The lowest shoot mass in the 4-6-leaf stage was recorded not in the absolute control, but in P-deficient treatments fertilized only with $\mathrm{N}$, which became intensely acidic. Plants in these treatments exhibited phytotoxic symptoms. On limed soil the symptoms of $\mathrm{P}$ deficiency were less perceptible. By the time the crop ripened the $\mathrm{P}$ effects had disappeared and the influence of liming was less obvious, as the plant roots had reached the lower soil layers, which were less acidic. The $\mathrm{N}$ rate became decisive, resulting in a surplus yield of $4 \mathrm{t} / \mathrm{ha}$, while a surplus of $2 \mathrm{t} / \mathrm{ha}$ was recorded as the after-effect of lim- 
ing. $\mathrm{K}$ fertilization was ineffective, as the soil was already well supplied with potassium.

- Leaf analysis on maize shoots in the 4-6-leaf stage indicated satisfactory supplies on the basis of $\mathrm{N}, \mathrm{K}, \mathrm{Ca}, \mathrm{Mg}, \mathrm{Mn}, \mathrm{Zn}, \mathrm{Cu}$ and $\mathrm{B}$ concentrations. Both $\mathrm{P}$ fertilization and liming led to improvements in the incorporation of phosphorus, resulting in the supply level improving from poor to satisfactory. $\mathrm{P} / \mathrm{Al}, \mathrm{P} / \mathrm{Zn}, \mathrm{P} / \mathrm{Cu}, \mathrm{Ca} / \mathrm{K}, \mathrm{Ca} / \mathrm{Sr}, \mathrm{Ca} / \mathrm{Zn}$ and $\mathrm{K} / \mathrm{Mg}$ antagonism could be detected, while $\mathrm{P} / \mathrm{Sr}$ synergism was observed in the shoot composition. The $\mathrm{Al}$ and Fe concentrations in the shoots were an order of magnitude greater than the "normal" composition. All these factors could have contributed to the abnormal development of the young maize plants and to the development of toxicity symptoms.

Table 1. Analytical data for the experimental soil profile after the experiment was laid out (Chernozem brown forest soil, clay loam, Kompolt). (1) Analytical parameters, according to the methodological guidelines of the Centre of Plant Protection and Agricultural Chemistry of the Ministry of Agriculture and Food (MÉM NAK 1978). (2) Symbol and depth of the soil horizon, in $\mathrm{cm}$.

Table 2. Mineral fertilizer rates $\left(\mathrm{kg} \mathrm{N}, \mathrm{P}_{2} \mathrm{O}_{5}, \mathrm{~K}_{2} \mathrm{O} /\right.$ ha/year) in the $\mathrm{B}-17$ experiment of the National Long-Term Mineral Fertilization Trials (OMTK) (Chernozem brown forest soil, Kompolt). (1) NPK level. (2) Applied under winter wheat. (3) Applied under maize in years $1-4,5-20$ and from the $21^{\text {st }}$ year.

Table 3. Treatments and operations in the maize experiment (OMTK B-1731) in 1996-1997. (1) Treatments and operations. (2) Year, month, day. (3) Notes. Maize hybrid Stira SC, sown at 5-7 cm depth with a spacing of $70 \times 30 \mathrm{~cm}$, with $16 \mathrm{~kg} / \mathrm{ha}$ seed.

Table 4. Effect of the treatments on the $\mathrm{pH}$ and hydrolytic acidity $\left(\mathrm{y}_{1}\right)$ of the ploughed layer and on the cc. $\mathrm{HNO}_{3}+$ cc. $\mathrm{H}_{2} \mathrm{O}_{2}$-soluble $\mathrm{Sr}$ and $\mathrm{P}$ reserves in the limed and control plots in 1997. (1) NP treatment. a) LSD $_{5 \%}$; b) Grand mean. (2) Limed. (3) Control. Note: Average quantities of other elements were independent of the treatments.

Table 5. Effect of the treatments on the $\mathrm{NH}_{4}$-acetate + EDTA-soluble element reserves of the ploughed layer in the limed (M) and control (Ø) plots in 1997. (1) NP treatment. a) $\mathrm{LSD}_{5 \%}$; b) Grand mean.

Table 6. Effect of liming on the $\mathrm{NH}_{4}$-acetate + EDTA-soluble element reserves of the ploughed layer in 1997, averaged over NPK treatments. Main effects of liming. (1) Element symbol. (2) Limed. (3) Ca control. (4) $\mathrm{LSD}_{5 \%}$. (5) Mean.

Table 7. Effect of $\mathrm{K}$ fertilization on the $\mathrm{NH}_{4}$-acetate + EDTA-soluble element reserves of the ploughed layer in 1997, averaged over NPCa treatments. Main effects of K. (1) Element symbol. (2) K fertilization. (3) K control. (4) $\mathrm{LSD}_{5 \%}$. (5) Mean. Note: Mean values, independently of treatments, for $\mathrm{Cu}, \mathrm{Cd}$ and $\mathrm{Mo}$.

Table 8. Effect of the treatments on the yield of maize in the 4-6-leaf stage and at harvest on limed (M) and control (Ø) plots in 1997. (1) NP treatment. a) $\mathrm{LSD}_{5 \%}$; b) Grand mean. (2) Fresh shoots, g/20 shoots. (3) Air-dry shoots, g/20 shoots. (4) Grain yield, $\mathrm{t} / \mathrm{ha}$.

Table 9. Effect of the treatments on the element composition of the air-dry shoots of 4-6-leaf maize on limed (M) and control (Ø) plots on 8 July 1997. (1): see Table 8. Note: Average values of listed elements, independently of the treatments.

Table 10. Effect of the treatments on the $\mathrm{Zn}, \mathrm{Sr}, \mathrm{Ba}$ and $\mathrm{Cu}$ contents of the air-dry shoots of 4-6-leaf maize on limed (M) and control (Ø) plots on 8 July 1997. (1): see Table 8 . 